\title{
The Effect of Economic History towards Students' Entrepreneurial Intention: A Planned Behavioral Approach
}

\author{
Atqo Akmal ${ }^{1}$, Sariyatun $^{2}$, and Warto ${ }^{3}$ \\ \{atqoakmal@gmail.com ${ }^{1}$, sari_fkip_uns@yahoo.co.id ${ }^{2}, \&$ warto_file@yahoo.co.id $\left.{ }^{3}\right\}$ \\ 1,2,3History Education Departement, Universitas Sebelas Maret. \\ Surakarta, Jawa Tengah, Indonesia.
}

\begin{abstract}
Several economic historians have argued about the beneficial combination of history and entrepreneurship. This is a quantitative comparative research to determine the effectiveness of economic history in encouraging students' entrepreneurial intention (EI). Theory of Planned Behavior on the entrepreneurship intention used as the theoretical framework to examine the way of history influenced entrepreneurial intention. Two random groups of students were compared to measure the difference between them as the result of economic history learning that integrated on the Indonesia History subject in the tertiary grade school. The results of the study showed that existed significant differences between both groups as the result of treatment on the experimental group. The Independent T-Test result showed that EI statistical analysis (sig. 2-tailed) valued 0.043 or below than $5 \%$ significance level. Based on the study, the entrepreneurial intention model that derived from Theory of Planned Behavior has empirically proved as explanatory framework to explain determinant factors that affect entrepreneurial intention.
\end{abstract}

Keywords: History Education, Economic History, Entrepreneurial Intention, Theory of Planned Behavior

\section{INTRODUCTION}

Unemployment and poverty are still major problems faced by Indonesia now and in the next few years. A large number of workforces and unemployment are not comparable to the available jobs. According to the Indonesian Central Bureau of Statistics in February 2018, the total Indonesian labor forces was 133.94 million people with open unemployment rate valued $5.13 \%$ of the total labor forces. The government of Indonesia is concerned to increase the number of new entrepreneurs. Reproducing new entrepreneurs is considered a strategic policy for reducing unemployment and poor people [1]. Departing from this reality, systematic efforts are needed to foster entrepreneurship among Indonesian.

J. A. Schumpeter believed that history was essential to the study of entrepreneurship, on his famous 1947 article on "Creative Response in Economic History" with this plea: "Economic historians and economic theorists can make an interesting and socially valuable journey together if they will" [2]. Though his article is most often cited for the distinction it 
developed between "adaptive" and "creative" responses in business, Schumpeter's main purpose was to call for the extensive use of historical methods in the study of entrepreneurship. For Schumpeter, the entrepreneurship shapes the whole course of subsequent events and their 'long-run' outcomes, the great extent to which its character differed from place to place and over the course of time suggested that a dynamic historical perspective was necessary in studying how it worked within economies. Schumpeter recognized that if his theory of entrepreneurship as the dynamic engine at the heart of capitalism was to have validity it needed to be studied as a historical phenomenon.

Most of the landmark entrepreneurship studies of this era embraced historical methods as essential to the study of entrepreneurship. Mc Clelland's The Achieving Society examined levels of achievement orientation indicator over long stretches of historical time [3]. Hagen's on the Theory of Social Change analyzed the historical emergence of innovation and technological creativity in England, Japan, Colombia, and Burma [4]. Wilken's on the comparative study of entrepreneurship delved even further into the histories of Great Britain, France, Germany, Japan, the United States, and Russia [5]. Moreover, the social science research of this era explored into the historical record on entrepreneurship in the developing regions [6], [7].

Various scholars and researchers have investigated the entrepreneurial intention of students, even though most of them are conducted for university students or the society as a whole and none of them linked history and the nature of entrepreneurship [8]-[15]. Many economic historian have called the role of history on the economic and entrepreneurship [2], [4], [6], [7], [16]-[18]. This study aims to examine how the effect of economic history towards students' entrepreneurial intention. Previously, Wadhwani \& Jones have tried to examine how historical models of change can contribute to theory and research on the competitive advantage of firms during periods of rapid innovation [19], but their study did not examine how history or historical models specifically could contribute on the entrepreneurship.

\section{METHODS}

\subsection{Theoretical Review}

In the psychological literature, intentions have proven the best predictor of planned behavior, particularly when that behavior is rare, hard to observe, or involves unpredictable time lags [20]. Theorists identified Ajzen's theory of reasoned action and theory of planned behavior [21], [22] as a useful explanatory mechanism for these results. According to this view, beliefs shape the formation of attitudes towards any prospective behavior, these attitudes drive the formation of intent to perform the behavior, and the intent causes the individual to act. Previously, Shapero \& Sokol [23] applied similar theoretical framework to the specific question of entrepreneurial intention, arguing that it was created by the perceived desirability of entrepreneurship, the perceived feasibility of acting entrepreneurially, and some individual propensity to act, then it was empirically validated by [24]. Ajzen's Theory of Planned Behavior (TPB) [21] was wider used on the entrepreneurship [15], [25]-[28]. According to the Theory of Planned Behavior, it captures the three motivational factors that influence behavior [21]:

1. Attitude towards the behavior (Personal Attraction, PA) refers to the degree to which the individual holds a positive or negative personal valuation about being an entrepreneur. 
2. Subjective norms $(\mathrm{SN})$ measure the perceived social pressure to carry out - or not to carry out - entrepreneurial behaviors. In particular, it would refer to the perception that "reference people" would approve of the decision to become an entrepreneur, or not;

3. Perceived behavioral control (PBC) is defined as the perception of the ease or difficulty of becoming an entrepreneur. It is, therefore, a concept quite similar to self-efficacy [29], and to perceived feasibility [23].

Liñán argued that to increase entrepreneurship intention firstly the students need to get "the awareness education." It refers to changes in soft outcomes like mindsets, attitudes, and desirability. To achieve these ends, students should learn about the nature of entrepreneurship and develop knowledge in fundamentals like entrepreneurs role in the society and economy, phases of the entrepreneurial process, entrepreneurs' tasks and challenges in the start-up phase, typical critical incidents, and crucial abilities and key competencies used by entrepreneurs [27].

Entrepreneurship Intention Model based on the Theory of Planned Behavior used to measure students' entrepreneurial intention along with determinant factor that influenced it. Many scholars both Indonesian and abroad have used this theoretical framework to investigate the entrepreneurial intention on secondary and tertiary students [25], [30], [31].

\subsection{Research Methods}

The research design is post-test only control group with equal randomize experimental and comparison group which both groups consist of 30 students in each group. Both groups have learned the Indonesian History subject. The treatment was given to the experimental group by providing awareness education through the local economic history instructional material during two months learning activity of Indonesian History Subjects and an assignment to create entrepreneurship ideas based on the local economic potential. On the comparison group, students were taught by usual approach of historical learning.

The instrument that was used to measure the data was Entrepreneurial Intention Questionnaire [28]. The instrument is adapted and reflected the construct of Entrepreneurial Intention Model [21], [27]. The instrument reliability test of the scales and items used Cronbach's Alpha, the values range from 0.773 to 0.943 . Thus, theoretically the instrument considered as reliable. Structural and content validities have been carefully considered when Liñán \& Chen developing the instrument [28]. All items are carefully matched to the theoretical construction of the model.

The data would be analyzed statistically using Statistical Package for the Social Sciences (SPSS) Version 20th depends on how statistical parametric and equalization of the data. To measure equalization of the data, normality and homogeneity of variance will be calculated using SPSS Version 20th to determine the right statistical approach for analyzing the data.

\subsection{Research Site}

The study was conducted in Sekolah Menengah Atas Negeri 1 Tembilahan (Tertiary Grade School No. 1 of Tembilahan), in Indragiri Hilir Regency, Province of Riau, Indonesia. It was conducted during January to February 2019.

\subsection{Research Hypothesis}

The hypotheses proposed in this study was: (H0) there was no statistically significant differences regarding the Entrepreneurial Intention between the experimental and comparison groups; (Ha) there were statistically significant differences regarding Entrepreneurial Intention the between experimental and comparison groups. 


\section{RESULT AND DISCUSSION}

In this study, perceived behavioral control (PBC) and subjective norms (SN) were not tested or compared, even though the data also collected. Entrepreneurial Intention (EI) and Personal Attitude (PA) toward entrepreneurship could be affected by awareness education which had been a treatment in this study through local economic history. Students' EI was measured to examine how the treatment had made differences between both groups. All of the questionnaires collected were properly answered, and thus all were used for data analysis.

Before performed statistical analysis, the data obtained than to be tested the data normality and homogeneity using SPSS Version 20th. It was to determine the data distribution and the equality degree of the data and to decide the types of statistical tests that were suitable to perform statistical analysis.

Table 1. Normality Data Test

\begin{tabular}{|c|l|r|r|}
\hline \multirow{3}{*}{ EI } & \multirow{2}{*}{ Group } & Lilliefors & \multicolumn{2}{|c|}{ Shapiro-Wilk } \\
\cline { 3 - 4 } & & Sig. & \multicolumn{2}{c|}{ Sig. } \\
\cline { 2 - 4 } & Experimental & $\mathbf{. 2 0 0}$ & $\mathbf{. 2 4 3}$ \\
\cline { 2 - 4 } & Comparison & $\mathbf{. 2 0 0}$ & $\mathbf{. 6 6 2}$ \\
\hline
\end{tabular}

Both experimental and comparison groups value of Lilliefors and Shapiro-Wilk test showed that EI p-value are greater than 5\% significance level (0.05). It was mean that the distribution of data is spread normally on both groups.

Tabel 2. Homogeneity of Data Variance

\begin{tabular}{|c|l|l|l|l|l|}
\hline \multirow{5}{*}{ EI } & \multicolumn{2}{|l|}{ Levene Statistic } & df1 & df2 & Sig. \\
\cline { 2 - 7 } & Based on Mean & 3.292 & 1 & 58 & $\mathbf{. 0 7 5}$ \\
\cline { 2 - 7 } & Based on Median & 2.358 & 1 & 58 & $\mathbf{. 1 3 0}$ \\
\cline { 2 - 7 } & Based on Median and with adjusted $d f$ & 2.358 & 1 & 56.935 & $\mathbf{. 1 3 0}$ \\
\cline { 2 - 7 } & Based on Trimmed Mean & 2.261 & 1 & 58 & $\mathbf{. 0 7 6}$ \\
\hline
\end{tabular}

Levene test showed that the homogeneity of the data was fulfilled. The value of Levene test on both variables based on the mean, median, median with adjusted df, and trimmed mean showed that they are higher than 5\% (0.05) significance level. Both normality and homogeneity test showed that the data are ready to be compared on the parametric Independent T-Test using SPSS Version $20^{\text {th }}$.

Table 3. The Result of Independent T-Test on Students' EI

\begin{tabular}{|c|c|c|c|c|c|c|c|c|}
\hline & & \multicolumn{7}{|c|}{$\mathrm{T}$ - Test for Equality of Means } \\
\hline & & \multirow[t]{2}{*}{$\mathrm{T}$} & \multirow[t]{2}{*}{ df } & \multirow[t]{2}{*}{$\begin{array}{l}\text { Sig. (2- } \\
\text { tailed) }\end{array}$} & \multirow[t]{2}{*}{$\begin{array}{c}\text { Mean } \\
\text { Difference }\end{array}$} & \multirow[t]{2}{*}{$\begin{array}{l}\text { Std. Error } \\
\text { Difference }\end{array}$} & \multicolumn{2}{|c|}{$\begin{array}{l}95 \% \text { Confidence } \\
\text { Interval of the } \\
\text { Difference }\end{array}$} \\
\hline & & & & & & & Lower & Upper \\
\hline EI & $\begin{array}{l}\text { Equal } \\
\text { variances } \\
\text { assumed }\end{array}$ & $\begin{array}{r}2.07 \\
2\end{array}$ & 58 & .043 & .46667 & .22525 & .01577 & .91756 \\
\hline
\end{tabular}




\begin{tabular}{|l|l|r|r|r|r|r|r|r|}
\hline $\begin{array}{l}\text { Equal } \\
\text { variances not } \\
\text { assumed }\end{array}$ & $\begin{array}{r}2.07 \\
2\end{array}$ & 55.505 & $\mathbf{. 0 4 3}$ & .46667 & .22525 & .01534 & .91799 \\
\hline
\end{tabular}

Independent $\mathrm{T}$-Test result showed statistically significant differences between the experimental group and the comparison group (Table 6). EI variable sig. (2-tailed) valued .043 or below than $5 \%$ significance level, it was mean that there was a significant difference existed between both groups' EI results and the $\mathrm{H}_{\mathrm{a}}$ was accepted.

\subsection{The Effect of Economic History towards Students' Entrepreneurial Intention}

The significant differences between both groups appeared as the result of the treatment on the experimental group. The statistical analysis result showed that entrepreneurial intentions (EI) in both groups have significant differences. Then the average value of EI in the experimental group was also higher than the comparison group. The statistical result shows that the treatment had impact on the students' entrepreneurial intention.

The intention of carrying out a planned behavior will depend on the person's attitudes towards that behavior [21]. According to Liñán "awareness education" is the way to improve students' personal attitude toward the entrepreneurship as well as the entrepreneurial intention, [27]. The treatment has accumulated pride and motivation of students to develop their hometown and to harness the local economic prospect, thus it would boost students' desirability to perform entrepreneurship or it would be influenced PA factor according to the Theory of Planned Behavior. As stated by Shapero \& Sokol that the entrepreneurial intentions depend on perceptions of personal desirability, feasibility, and propensity to act [23].

Although not without debate, entrepreneurship could be defined as the discovery, evaluation, and exploitation of the opportunity [32]. It essentially involves the pursuit of opportunities without regard to the resource limitations [33]. During the treatment, students analyzed the historical changes of local economic history which are useful for them to explore the economic opportunity of the region. The dynamic changes of the economic history help students to learn about the local economic prospect and gain lessons from the up and down of the local commodity. In line with it, the role of historical change on the firm to respond to the disruptive (innovative change) has explained by Wadhwani \& Jones, they have found that the historical change -evolutionary, dialectical, and constitutive- can be used to deepen the foundations of dynamic capabilities on running a firm through disruptive period [19].

George Mead explained on the relationship between individual identity and society. $\mathrm{He}$ theorizes that preexisting social structure and conditions shape a person's identity [34]. The local main commodity has been an icon and pride of the students' nearby society. Thus the commodity has being "collective identity" of the local society, because it has shared an emotional connection within the students and their society. Polletta \& Jasper defined collective identity as an individual's cognitive, moral, and emotional connections with a broader community, category, practice, or institution [35]. Consequently, it had also influenced the desirability of experimental group by growing students' pride and motivation towards the main commodity of the region.

\subsection{Limitations}

This study has some limitations and suggested that the results of this study should be interpreted carefully. First, since the collected data was based on the perceptions of the 
students, limitation might appear on a possible difference between "perceptions" and "reality". Obviously, there is always a risk that the perceptions of students might be different from reality. Second, this study just limited on the Indragiri Hilir region, a regency level unit in Indonesia, it strongly noted that the treatment would only effect on the students in this region. Third, the scope of sample is relatively cannot covered the whole of society even randomize sampling technique has been applied, because it just engages one school of the experiment. Fourth, for more comprehensive analysis it is important to measure and consider social and cultural factors (SN) and perceived behavioral control (PBC) which could shape the students' entrepreneurial intention, but in this study the two factors are not being considered and only focused on the personal attitude factor. Furthermore, future studies in different society and different historical treatment through the history education need to be undertaken for reinforcing the findings of this study and a more deepen explanation of the factors affecting student's entrepreneurial intention.

\section{CONCLUSION}

The result of the study showed that the economic history has encouraged students' entrepreneurial intention. It could be assumed that history could contribute to the nature of entrepreneurship. The treatment on this study used the local economic history as a stimulant to improve students' entrepreneurial intention by providing historical perspectives on economic changes of the local economic history to boost and motivate students' pride about their regional economic commodity. As the result of the treatment, students that have been given treatment gain higher average value of personal attitude toward entrepreneurship and subsequently encourage students' intention to perform a start-up someday. Statistical analysis showed a significant difference between both groups which as the result of significant improvement of the experimental group's entrepreneurial intention.

According to the study, the improvement of students' personal attitude toward entrepreneurship has positive relation to students' entrepreneurial intention. The role of awareness education as the way to improve personal attitude toward entrepreneurship is also confirmed. Indeed based on the study, the entrepreneurial intention model framework that derived from Theory of Planned Behavior has empirically proved as explanatory framework to explain determinant factors that affect entrepreneurial intention.

\section{REFERENCES}

[1] D. Purwana, U. Suhud, T. Fatimah, and A. Armelita, "Antecedents of secondary students' entrepreneurial motivation,” J. Entrep. Educ., 2018.

[2] J. A. Schumpeter, "The Creative Response in Economic History," J. Econ. Hist., 1947.

[3] D. McClelland, "Entrepreneurial Behavior," Achiev. Soc., 1961.

[4] E. E. Hagen, "How Economic Growth Begins: A Theory of Social Change," J. Soc. Issues, 1963.

[5] A. Oberschall, "Entrepreneurship: A Comparative and Historical Study. By Paul H. Wilken. Norwood, N.J.: Ablex, 1979. 320 pp. \$19.95,” Soc. Forces, 2011.

[6] M. Edel and P. Kilby, "Entrepreneurship and Economic Development," Am. J. Agric. Econ., 2006.

[7] W. Naudé, "Entrepreneurship and Economic Development: An Introduction," in Entrepreneurship and Economic Development, 2016.

[8] S. H. Ang and D. G. P. Hong, "Entrepreneurial spirit among East Asian Chinese," Thunderbird Int. Bus. Rev., 2002. 
[9] T. M. Begley, W. L. Tan, A. B. Larasati, A. Rab, E. Zamora, and G. Nanayakkara, "The relationship between socio-cultural dimensions and interest in starting a business: A multi-country study," Front. Entrep. Res. 1997, 1997.

[10] R. Henderson and M. Robertson, "Who wants to be an entrepreneur? Young adult attitudes to entrepreneurship as a career," Educ. + Train., 1999.

[11] S. M. Lee, D. Chang, and S. Lim, "Impact of Entrepreneurship Education: A Comparative Study of the U.S. and Korea," Int. Entrep. Manag. J., 2005.

[12] P. Mares, T. Costa, and S. Galina, "Student's Entrepreneurial Intention: ESCE and FEA Comparison,” XXVI Jornadas Luso-Espanholas Gestão Cient., 2016.

[13] M. Scott and D. Twomey, "The long-term supply of entrepreneurs: students' career aspirations in relation to entrepreneurship," J. Small Bus. Manag., 1988.

[14] D. Turker and S. S. Selcuk, "Which factors affect entrepreneurial intention of university students?," J. Eur. Ind. Train., 2009.

[15] J. M. Veciana, M. Aponte, and D. Urbano, "University Students' Attitudes Towards Entrepreneurship: A Two Countries Comparison,” Int. Entrep. Manag. J., 2005.

[16] J. A. Schumpeter and R. Swedberg, "Economic Theory and Entrepreneurial History," in Essays, 2018.

[17] R. Daniel Wadhwani and G. Jones, "Schumpeter's Plea: Historical Reasoning in Entrepreneurship Theory and Research," in Organizations in Time, 2014.

[18] G. Jones and P. H. Wilken, "Entrepreneurship: A Comparative and Historical Study.," Econ. Hist. Rev., 2006.

[19] R. D. Wadhwani and G. G. Jones, "Historical Change and the Competitive Advantage of Firms: Explicating The 'Dynamics' in the Dynamic Capabilities Framework," 2016.

[20] N. F. Krueger, M. D. Reilly, and A. L. Carsrud, "Competing models of entrepreneurial intentions," J. Bus. Ventur., 2000.

[21] I. Ajzen, "The theory of planned behavior," Organ. Behav. Hum. Decis. Process., 1991.

[22] I. Ajzen, "From Intentions to Actions: A Theory of Planned Behavior," in Action Control, 2011.

[23] A. Shapero and L. Sokol, "Social dimensions of entrepreneurship," in The encyclopedia of entrepreneurship, 1982.

[24] N. F. Krueger Jr, "The Impact of Prior Entrepreneurial Exposure on Perceptions of New Venture Feasibility and Desirability.," Entrep. Theory Pract., 1993.

[25] A. Tkachev and L. Kolvereid, "Self-employment intentions among russian students," Entrep. Reg. Dev., 1999.

[26] N. F. Krueger and A. L. Carsrud, "Entrepreneurial intentions: Applying the theory of planned behaviour,” Entrep. Reg. Dev., 1993.

[27] F. Liñán, "Intention-based models of entrepreneurship education," Piccola Impresa/Small Bus., 2004.

[28] Linan F. and Chen Y. W., "Development and cross-cultural application of a specific instrument to measure entrepreneurial intentions," Entrep. Theory Pract., 2009.

[29] A. Bandura, W. H. Freeman, and R. Lightsey, "Self-Efficacy: The Exercise of Control," J. Cogn. Psychother., 2018.

[30] G. E. N. Richard Denanyoh1, Kwabena Adjei2, "Factors That Impact on Entrepreneurial Intention of Tertiary Students in Ghana," Int. J. Bus. Soc. Res., 2015.

[31] D. Purwana, U. Suhud, and S. M. Rahayu, "Entrepreneurial intention of secondary and tertiary students: Are they different?," Int. J. Econ. Res., 2017.

[32] S. Shane and S. Venkataraman, "The promise of entrepreneurship as a field of research," in Entrepreneurship: Concepts, Theory and Perspective, 2007. 
[33] H. H. Stevenson and D. E. Gumpert, "The Heart of Entrepreneurship," Harv. Bus. Rev., 1985.

[34] T. Abel, G. H. Mead, and C. W. Morris, "Mind, Self, and Society," Am. J. Psychol., 2006.

[35] F. Polletta and J. M. Jasper, "Collective Identity and Social Movements," Annu. Rev. Sociol., 2002. 